much brighter than Venus, and its flight was from $324^{\circ}+67^{\circ}$ to $35^{\circ} \frac{1}{2}+55^{\circ}$, which it traversed in $2 \mathrm{sec}$. This magnificent object was evidently one of the Quadrantids from a radiant at $228^{\circ}+54^{\circ}$. It would be interesting to hear of another observation of it, and also of remarkable meteors reported by Mrs. Wilson as under :-

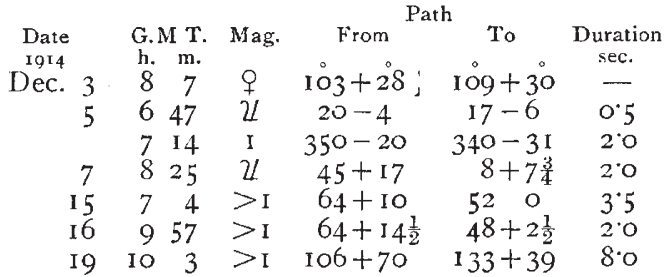

The last in the table had an extraordinarily slow flight, the duration being carefully estimated as $8 \mathrm{sec}$.

Water Vapour in Mars's Atmosphere.-Lowell Observatory Bulletin, No. 65 , contains a paper by Dr. F. W. Very on the intensification of oxygen and water vapour bands in the Martian spectrum. The spectrograms of Mars and the moon were taken by Dr. V. M. Slipher, at the Lowell Observatory, on February 6, I914, and on the plates taken C, B, and $a$ have been measured at the Westwood Astrophysical Observatory, with a spectral band comparator. Each plate contained two sets of spectrograms, and each set consisted of a central Martian spectrum flanked by two of the moon, taken at nearly the same altitude and within a few minutes of each other. By the use of a new stain the photographic sensitiveness of the plate at $a$ makes the intensities of $a$ more accurate. The observations confirm the supposition that the melting snows of the Martian Arctic regions are the sole source of aqueous vapour in the Martian air, and that the equatorial regions are excessively dry. They indicate also that the actual amount of oxygen in the Martian atmosphere is about half as great as upon the earth.

a Second Harvard Map of the Sky.-Harvard College Observatory Circular, No. $7 \mathrm{I}$, contained a description of a photographic map of the entire sky, the map consisting of double contact prints on glass of fifty-five photographs taken with anastigmatic lenses, each having an aperture of $I$ in. and a focal length of about 13 in.; the cameras were mounted at Cambridge and Arequipa. Each plate was 8 by ro in. in size, and included a region of $30^{\circ}$ square. The total number of stars shown was $1,683,000$, and the limiting magnitude about II.5. Circular No. ${ }^{8} 5$ now contains an announcement by Prof. E. C. Pickering that a second set of plates has been selected, and another map of the sky has been prepared by Prof. King. In these photographs the centres of the plates coincide with the corners of the first set; this was done as it was found that owing to the large area of the sky covered in the first set the stars near the corners were distorted, and faint stars were not recorded there. The circular contains a catalogue of the plates employed. It is proposed to issue this new set of photographs at the same price as the first, namely, I5.00 dollars-a price, as is stated, somewhat less than cost.

The Short-Period Variable, SZ Tauri.-An investigation of the light curve of the short-period variable, $\mathrm{SZ}$ Tauri, is contained in the Harvard College Observatory Circular, No. I86, and was made by Miss Leavitt. Prof. Schwarzschild, in I9II, published the elements of this variable, basing them on observations by Prof. Hertzsprung, and the times of minima were found to be represented by the formula, J.D. $2,418,724 \cdot 16$ M.E.Z. $+3 d \quad 1484$ E. It was with NO. 2358 , VOL. 94.] the object of securing a more precise period that the present investigation was undertaken, and 210 plates taken at the observatory between October, I89I, and February, 19I4, have been utilised for this purpose. A table is given showing all the observations of the variable used, and a curve is added indicating the nature of the light variation. By reducing the observations by the above formula it was found that those previous to 1903 were not satisfied. They were, however, all well represented by the formula for times of maximum, J.D. $2,410,000 \cdot 60$ G.M.T. $+3 d 1487$ E, and this has been used in computing the epochs and phases given in the above-mentioned table.

One Hundred New Double Stars.--Dr. R. G. Aitken, in the Lick Observatory Bulletin, No. 264, gives the twenty-third list of double star measures, the present one containing one hundred new double stars. The mean results of his measures are arranged in the same form as his earlier lists. The angular separation of the pairs ranges from $0 \cdot 17^{\prime \prime}$ to $4.78^{\prime \prime}$.

\section{PRIZE AWARDS OF THE PARIS ACADEMY OF SCIENCES FOR I9I4.}

Geometry.-The Francœur prize to A. Claude, for the whole of his astronomical work, and the Poncelet prize to M. Lebesgue. The Grand prize of the mathematical sciences was not awarded.

Mechanics.-The Montyon prize to Ed. W. Bogaert, for his memoir on the gyrostatic effect and its applications; the Henri de Parville prize between Jean Rey (rooo francs), for his work in mechanics and electromechanics, and Marcel Biver (500 francs), for his pamphlet on a system of transmission and transformation of movement. The question proposed for the Fourneyron prize, the theoretical and experimental study of the question of combustion or explosion turbines, is postponed until 19I7, as no memoir was received.

Astronomy.-The Lalande prize to J. N. Guillaume, for the whole of his astronomical work; the Valz prize equally between Pierre Salet and Stanislas Chevalier; the Janssen prize to René Jarry-Desloges, for his studies on the planets, especially Mars; the Damoiseau prize to $M$. Gaillot, for improvements in Le Verrier's tables of Jupiter. No award was made of the Pierre Guzman prize.

Geography.-The Tchihatchef prize between Commandant Audemard (2000 francs) and Paul Labbé (Iooo francs), the former for his hydrographical work in China, the latter for his work in Asiatic Russia in the fields of natural history, anthropology, and ethnography; the Gay prize to $R$. de la Brosse, for his hydraulic studies in the Alps; the Binoux prize between Ernest Esclangon (I500 francs), for his observations on the acceleration of gravity in the southwest of France, Alfred Vialay (500 francs), for his contribution to the study of the relations existing between the atmospheric circulation, atmospheric electricity, and terrestrial magnetism, and Paul Schwartz and Fernand Villatte (50o francs jointly), for the whole of their work; the Delalande-Guérineau prize to Jacques Liouville, for his work in the Antarctic regions.

Navigation.-The extraordinary prize of the Navy is divided between M. Roussilhe (2000 francs), for his works on the French Congo, M. Poincet (2000 francs), for his studies on the association of screw propellers and turbines, M. Crémieux ( 1500 francs), for his work on the powders of the Navy, and M. Lafon (500 francs), for his memoir on naval and military aeronautics (France and abroad); the Plumey prize between M. Dumanois (200o francs), for his memoir on the application of the internal-combustion motor to 
warships, M. Moritz (1500 francs), for his work on thermal motors in their relations with thermodynamics, and M. Schwartz (500 francs), for his work as a whole.

Physics.-The Hébert prize to M. Mauduit, for his treatise on electric machinery; the Hughes prize to Louis Benoist, for his researches on the X-rays; the L. La Caze prize to Jean Perrin, for his work on the kathode rays, $\mathrm{X}$-rays, and Brownian motion; the Victor Raulin prize to Mme. Marchand.

Chemistry.-The Jecker prize to Marcel Delépine, for his work in organic, inorganic, and general chemistry; the Cahours prize to MM. André Meyer and Vavon (in equal parts); the Montyon prize (unhealthy trades) is not awarded; the La Caze prize to $M$. Debierne, for his researches on the radio-active elements.

Mineralogy and Geology.-The Fontannes prize to Jean Boussac, for his memoir on the evolution of the Cerithider in the mesonummulitic of the Paris basin.

Botany.-The Desmazières prize to MM. de Istvanffi and Palinkas, for their study of the mildew of the vine, a mention being accorded to $\mathrm{M}$. Bruchmann; the Montagne prize divided between $M$. Sauvageau (Iooo francs) for his monograph on the Cystoseira, and M. Coppey (50o francs), for his bryological researches; the de Coincy prize to M. Gard, for his studies on hybrids of Cistus.

Anatomy and Zoology.-The Savigny prize to J. M. R. Surcouf; the Cuvier prize to M. Bordas, for his anatomical researches; the Thore prize to J. Feytaud, for his researches on ants.

Medicine and Surgery.-Montyon prizes (500 francs each) to H. Bierry, for his works on the glycogenic function, Ch. Nicolle, L. Blaizot, and E. Conseil (jointly), for their works on the etiology and prophylaxy of recurring fever, and E. Pinoy for his researches on the pathogenic fungi. Mentions, I500 francs each, to Ed. Delorme, for his memoir on the direct surgical treatment of cardo-pericardiac symphysis, E. Maurel, for his work on alimentation and nutrition in normal and pathological states, and $P$. Chausse, for his work on tuberculosis. Citations were accorded to André Broca, for his book on infant surgery; Robert Picqué, for his practical treatise on surgical anatomy and operative medicine; M. Roussy, for his book on five original methods for measuring the surface of the skin of the human body; M. Aynaud, for various memoirs on the question of the third element of the blood; M. Brunon, for his works relating to tuberculosis; MM. Gautrelet and Laubie; and $M$. Couvelaire, for his introduction to uterine obstetrical surgery; the Barbier prize in equal parts between H. Carré, for his memoirs on contagious agalaxy of the kid and goat, and Albert Ranc, for his studies on the physiological action of light; the Bréant prize between $H$. Vincent ( 3000 francs), for his works on the typhoid bacillus and on typhoid fever, and O. Arnaud (200o francs), for his work on cholera in the Greek army during the Balkan war; the Godard prize to Antoine Lacassagne, for his studies on the action of the X-rays on the ovary; the Baron Larrey prize divided equally between Dr. Reverchon, for his medico-military studies on the second Balkan war, and $\mathrm{H}$. Billet, for his work on the treatment of skull wounds caused by small projectiles; the Bellion prize between M. Gorini (Iooo francs), for his work on vaccines, the bacteriology of milk, and pathogenic micro-organisms, and M. Marotel (400 francs), for his researches on parasitic diseases, Raoul Dupuy receiving an honourable mention for his memoir on backward children and their treatment; the Mège prize to M. Bruntz, for his researches on the excretory organs of vertebrates and invertebrates.
Physiology.-.The Montyon prize (experimental physiology) to A. Mayer and G. Schæeffer (jointly), for their work on the lipocytic coefficient; the Philipeaux prize to Pierre Girard, for his researches on electrical osmosis; the Lallemand prize between Henri Piéron and René Legendre (goo francs jointly), for their memoir on the physiological problem of sleep, and J. Mawas ( 900 francs), for the whole of his work on the anatomy and physiology of the nervous membrane of the eye in vertebrates and in man, André Barbé being accorded a mention; the Pourat prize is not awarded; the La Caze prize (physiology) to E. Gley, for the whole of his work; the Martin-Damourette prize between M. Fauré-Fremiet (10oo francs), for his memoir on the germinative cycle in Ascaris megalocephala, and A. Lanzenberg (400 francs), for his work on ammonia and urea : origin, methods of estimation.

Statistics.-The Montyon prize to René Worms, for his studies on sexuality in French births and on agricultural associations.

History of the Sciences.-The Binoux prize is not awarded.

General Prizes.-A Berthelot medal to M. Debierne; the Gegner prize (2000 francs) to J. H. Fabre; the Lannelongue prize between Mme. Cusco and Mme. Rück; the Trémont prize to Charles Frémont; the Wilde prize between Perrier de la Bathie (3000 francs), for his geological explorations in Madagascar, and M. Schulhof (2000 francs); the Lonchampt prize to M. Javillier, for his work on the biological properties of zinc salts; the Saintour prize between R. Bigeard and H. Guillemin (I50o francs jointly), for their work on fungi, and J. Révil ( $5_{500}$ francs), for his geological work; the Henri de Parville prize between M. Berget (Iooo francs), M. Houllevigue (Iooo francs), M. Joubin (1000 francs), M. Altermann (500 francs), and M. Coupin ( 500 francs); the Houllevigue prize to $M$. Vershaffel; the Caméré prize to Augustin Mesnager; the Jerome Ponti prize between Henri Bröllemann (2500 francs), for his work on the Myriapods, and M. Pelourde (Iooo francs), for his researches on plant palæontology; the Serres prize to A. Prenant, for his work in histology, cytology, and embryology; the Jean Jacques Berger prize (I5,000 francs) to the Marquis de Vogüé, for the military hospital organised by the institute; the prize founded by the Marquise de Laplace to M. Sasportès; the prize founded by Félix Rivot between MM. Sasportès, Lévy, Jeannin, and Pélissonnier; the Bordin and Henri. Becquerel prizes are not awarded, and the Gustave Roux prize is post. poned to I9I 5 .

\section{ECONOMIC GEOLOGY IN THE UNITED STATES.}

WE have received from the United States Geological Survey a number of bulletins dealing with economic geology, namely:-"Reconnaissance of Oil and Gas Fields in Wayne and McCreary Counties, Kentucky," "Oil and Gas in the Western Part of the Olympic Peninsula, Washington," "The Ore Deposits of North-Eastern Washington," "Mining Districts of the Dillon Quadrangle, Montana," "Electric Activity in Ore Deposits." "The first two of these possess merely a local interest; the same is true to a large extent of the two next on the list, though their perusal will well repay the students of mineral deposition, more especially in the case of the bulletin on the Dillon Quadrangle, which is from the pen of Mr. Alexander N. Winchell. The last pamphlet contains an interesting study of the possible modes of development of electromotive force in ore deposits and of some of its effects, amongst which latter the deposition of the precious metals in the metallic state by electrolytic

$$
\text { No. 2358, VOL. 94] }
$$

